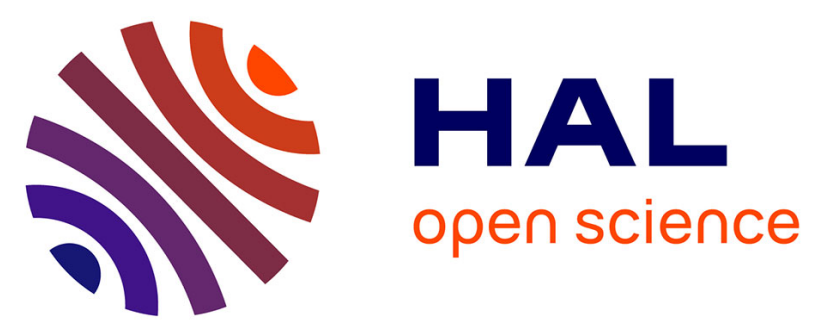

\title{
Synthesis and Characterization of Isomerically Pure anti- and syn-Anthradiindole Derivatives
}

Jean-Yves Balandier, N. Henry, Jean-Baptiste Arlin, Lionel Sanguinet, Vincent Lemaur, Claude Niebel, Basab Chattopadhyay, Alan Kennedy, Philippe Leriche, Philippe Blanchard, et al.

\section{To cite this version:}

Jean-Yves Balandier, N. Henry, Jean-Baptiste Arlin, Lionel Sanguinet, Vincent Lemaur, et al.. Synthesis and Characterization of Isomerically Pure anti- and syn-Anthradiindole Derivatives. Organic Letters, 2013, 15 (2), pp.302-305. 10.1021/ol303214j . hal-03344557

\section{HAL Id: hal-03344557 \\ https://univ-angers.hal.science/hal-03344557}

Submitted on 15 Sep 2021

HAL is a multi-disciplinary open access archive for the deposit and dissemination of scientific research documents, whether they are published or not. The documents may come from teaching and research institutions in France or abroad, or from public or private research centers.
L'archive ouverte pluridisciplinaire HAL, est destinée au dépôt et à la diffusion de documents scientifiques de niveau recherche, publiés ou non, émanant des établissements d'enseignement et de recherche français ou étrangers, des laboratoires publics ou privés. 


\title{
Synthesis and Characterization of Isomerically Pure anti- and syn-Anthradiindole Derivatives
}

2013

Vol. 15, No. 2

302-305

\author{
Jean-Yves Balandier, ${ }^{,},{ }^{\dagger}$ Nicolas Henry, ${ }^{\dagger}$ Jean-Baptiste Arlin, ${ }^{\dagger}$ Lionel Sanguinet, ${ }^{\ddagger}$ \\ Vincent Lemaur, ${ }^{\S}$ Claude Niebel, ${ }^{\dagger}$ Basab Chattopadhyay, ${ }^{\dagger}$ Alan Robert Kennedy," \\ Philippe Leriche, ${ }^{\ddagger}$ Philippe Blanchard, ${ }^{\ddagger}$ Jérôme Cornil, ${ }^{\S}$ and Yves Henri Geerts ${ }^{\dagger}$
}

Université Libre de Bruxelles (ULB), Faculté des Sciences, Laboratoire Chimie des Polymères, CP 206/1, Boulevard du Triomphe, 1050 Bruxelles, Belgium, LUNAM Université, MOLTECH-Anjou UMR CNRS 6200, Université d'Angers, 2 Bd Lavoisier, 49045 Angers Cedex, France, Université de Mons (UMons), Service de Chimie des Matériaux Nouveaux, Place du Parc 20, 7000 Mons, Belgium, Department of Pure and Applied Chemistry, WestCHEM, University of Strathclyde, 295 Cathedral Street, Glasgow UK G1 1XL, United Kingdom

jbalandi@ulb.ac.be

Received November 21, 2012

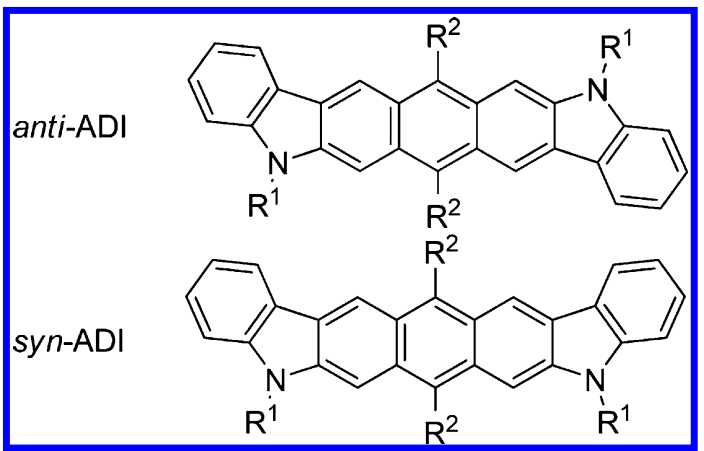

Synthesis, isolation, and characterization of isomerically pure syn- and anti-anthradiindole (ADI) derivatives are described. The anti- and syn-ADI structures are demonstrated by ${ }^{13} \mathrm{C}$ NMR spectroscopy and by single-crystal X-ray diffraction. The spectroscopic and electrochemical properties as well as the stability of these newly synthesized $\pi$-conjugated systems are evaluated and supported by quantum-chemical calculations.

Fused linear (hetero)acenes ${ }^{1}$ are among the most used semiconductors in organic electronics. An important library of those derivatives showing good electronic properties is now available for OFET, ${ }^{2}$ solar cell, ${ }^{3}$ and OLED ${ }^{4}$ applications, going from the well-known pentacene ${ }^{5}$ to its structural analogues including heteroatoms in their conjugated $\pi$-systems such as anthradithiophenes (ADT) derivatives. ${ }^{6}$

\footnotetext{
Université Libre de Bruxelles (ULB).

LUNAM Université.

${ }^{\S}$ Université de Mons (UMons).

"University of Strathclyde.

(1) (a) Anthony, J. E. Chem. Rev. 2006, 106, 5028. (b) Takimiya, K.; Shinamura, S.; Osaka, I.; Miyazaki, E. Adv. Mater. 2011, 23, 4347. (c) Wang, C.; Dong, H.; Hu, W.; Liu, Y.; Zhu, D. Chem. Rev. 2012, 112, 2208. (d) Anthony, J. E. Angew. Chem., Int. Ed. 2008, 47, 452.

Over the past 2 years, intensive work has been carried out in order to produce isomerically pure (hetero)acene ${ }^{7}$ instead of mixtures of $s y n$ - and anti-isomers isolated during previous decades. $^{3 a, 6,8}$ For instance, we have previously reported the first synthesis of pure dialkyl-substituted anti-ADT. ${ }^{7 \mathrm{a}}$ Indeed, materials obtained from pure isomer

(2) (a) Nakano, N.; Niimi, K.; Miyazaki, E.; Osaka, I.; Takimiya, K. J. Org. Chem. 2012, 77, 8099. (b) Matsumura, D.; Kitazawa, K.; Terai, S.; Kochi, T.; Ie, Y.; Nitani, M.; Aso, Y.; Kakiuchi, F. Org. Lett. 2012, 14, 3882. (c) Katsuta, S.; Tanaka, K.; Maruya, Y.; Mori, S.; Masuo, S.; Okujima, T.; Uno, H.; Nakayama, K.; Yamada, H. Chem. Commun. 2011, 47, 10112. (d) Lei, T.; Zhou, Y.; Cheng, C. Y.; Cao, Y.; Peng, Y.; Bian, J.; Pei, J. Org. Lett. 2011, 13, 2642. (e) Katsuta, S.; Miyagi, D.; Yama, H.; Okujima, T.; Mori, S.; Nakayama, K.; Uno, H. Org. Lett. 2011, 13, 1454. (f) Yamamoto, T.; Takimiya, K. J.Am. Chem. Soc. 2007, 129, 2224. (g) Tang, M. L.; Reichardt, A. D.; Siegrist, T.; Mannsfeld, S. C. B.; Bao, Z. J. Am. Chem. Soc. 2009, 131, 3733. 
derivatives are supposed to allow higher mobilities in OFETs. Recently, Takimiya and co-workers have thus reported the synthesis of pure anti-anthradiselenophene and anti-anthradifuran as well as their FET characterizations. ${ }^{2 a}$ Although many studies have been described on anthradichalcogenophene (ADC) derivatives including sulfur, oxygen, or selenium atoms, the synthesis of anthradiindole (ADI) including nitrogen atoms remains unknown. In this context, we have been interested in the preparation and separation of the first isomerically pure $s y n$ - and anti-isomers of ADI derivatives. In order to fulfill solubility requirements and to slow down the unavoidable photoinduced degradation of the ADI, octyl chains were attached on nitrogen atoms and thienyl groups were substituted on the aromatic ring located in the center of their backbones, respectively. Indeed, it has been shown for ADC derivatives that the presence of substituents such as silyl, thienyl, or phenyl derivatives on the center of their aromatic cores (5,11-positions for pentacene or ADT, for instance) considerably improve their stability toward photo-oxidation. ${ }^{9}$ The spectroscopic and electrochemical properties of these semiconductors were evaluated and supported by quantum-chemical calculations.

ADI derivatives were synthesized as presented in Scheme 1. 1-Octyl-1H-indole-3-carboxaldehyde (2) was synthesized in $92 \%$ yield by reaction of 1 -iodooctane with $1 H$-indole-3-carboxaldehyde (1) in the presence of

(3) (a) Lloyd, M. T.; Mayer, A. C.; Subramanian, S.; Mourey, D. A.; Herman, D. J.; Bapat, A. V.; Anthony, J. E.; Malliaras, G. G. J. Am. Chem. Soc. 2007, 129, 9144. (b) Gorodetsky, A. A.; Cox, M.; Tremblay, N. J.; Kymissis, I.; Nuckolls, C. Chem. Mater. 2009, 21, 4090. (c) Jiang, Y.; Okamoto, T.; Becerril, H. A.; Hong, S.; Tang, M. L.; Mayer, A. C.; Parmer, J. E.; McGehee, M. D.; Bao, Z. Macromolecules 2010, 43, 6361.

(4) (a) Lee, Y. H.; Wu, T. C.; Liaw, C. W.; Wen, T. C.; Guo, T. F.;

Wu, Y. T. J. Mater. Chem. 2012, 22, 11032. (b) Odom, S. A.; Parkin, S. R.; Anthony, J. E. Org. Lett. 2003, 5, 4245.

(5) Laquindanum, J. G.; Katz, H. E.; Lovinger, A. J.; Dodabalapur, A. Chem. Mater. 1996, 8, 2542 .

(6) Laquindanum, J. G.; Katz, H. E.; Lovinger, A. J. J. Am. Chem. Soc. 1998, 120, 664 .

(7) (a) Tylleman, B.; Vande Velde, C. M. L.; Balandier, J. Y.; Stas, S.; Sergeyev, S.; Geerts, Y. H. Org. Lett. 2011, 13, 5208. (b) Li, Z.; Lim, Y. F.; Kim, J. B.; Parkin, S. R.; Loo, Y. L.; Malliaras, G. G.; Anthony, J. E. Chem. Commun. 2011, 47, 7617. (c) Lehnherr, D.; Hallani, R.; McDonald, R.; Anthony, J. E.; Tykwinski, R. R. Org. Lett. 2012, 14, 62. (d) Shinamura, S.; Osaka, I.; Miyazaki, E.; Nakao, A.; Yamagishi, M.; Takeya, J.; Takimiya, K. J. Am. Chem. Soc. 2011, 133, 5024. (e) Mamada, M.; Minamiki, T.; Katagiri, H.; Tokito, S. Org. Lett. 2012, 14, 4062. (f) Lehnherr, D.; Waterloo, A. R.; Goetz, K. P.; Payne, M. M.; Hampel, F.; Anthony, J. E.; Jurchescu, O. D.; Tykwinski, R. R. Org. Lett. 2012, 14, 3660 .

(8) (a) Jurchescu, O. D.; Subramanian, S.; Kline, R. J.; Hudson, S. D.; Anthony, J. E.; Jackson, T. N.; Gundlach, D. J. Chem. Mater. 2008, 20, 6733. (b) Conrad, B. R.; Chan, C. K.; Loth, M. A.; Parkin, S. R.; Zhang, X.; DeLongchamp, D. M.; Anthony, J. E.; Gundlach, D. J. Appl. Phvs. Lett. 2010, 97, 133306. (c) Jaquith, M. J.; Anthony, J. E.; Marohn, J. A. J. Mater. Chem. 2009, 19, 6116. (d) Chen, M. C.; Kim, C.; Chen, S.-Y.; Chiang, Y.-J.; Chung, M. C.; Facchetti, A.; Marks, T. J. J. Mater. Chem. 2008, 18, 1029.

(9) (a) Balandier, J. Y.; Quist, F.; Sebaihi, N.; Niebel, C.; Tylleman, B.; Boudard, P.; Bouzakraoui, S.; Lemaur, V.; Cornil, J.; Lazzaroni, R.; Geerts, Y. H.; Stas, S. Tetrahedron 2011, 67, 7156. (b) Balandier, J. Y.; Quist, F.; Stas, S.; Tylleman, B.; Ragoen, C.; Mayence, A.; Bouzakraoui, S.; Cornil, J.; Geerts, Y. H. Org. Lett. 2011, 13, 548. (c) Ono, K.; Totani, H.; Hiei, T.; Yoshino, A.; Saito, K.; Eguchi, K.; Tomura, M.; Nishida, J. I.; Yamashita, Y. Tetrahedron 2007, 63, 9699. (d) Payne, M. M.; Delcamp, J. H.; Parkin, S. R.; Anthony, J. E. Org. Lett. 2004, 6, 1609. (e) Anthony, J. E.; Brooks, J. S.; Eaton, D. L.; Parkin, S. R. J. Am. Chem. Soc. 2001, 123, 9482. (f) Wang, J.; Liu, K.; Liu, Y. Y.; Song, C. L.; Shi, Z. F.; Peng, J. B.; Zhang, H. L.; Cao, X. P. Org. Lett. 2009, 11, 2563. potassium carbonate. Then, the dialdehyde derivative 3 was prepared in $55 \%$ yield through four one-pot successive steps by analogy to a procedure described in the literature ${ }^{10}$ for the synthesis of 1,2-dimethyl- $1 H$-indole-3-carboxaldehyde. Compound 2 reacted with lithium 4-methylpiperazin1-ide (formed in situ by reaction of 1-methylpiperazine with $n$ - $\mathrm{BuLi}$ ) to afford intermediate $\mathbf{2 a}$, which was then lithiated using an excess of $n$-BuLi to give $2 \mathbf{b}$. 1-Octyl- $1 H$ indole-2,3-dicarbaldehyde (3) was then obtained by reaction of the lithiated intermediate $\mathbf{2 b}$ with $N, N$-dimethylformamide, after hydrolysis. Condensation of the dialdehyde 3 with cyclohexane-1,4-dione in a $5 \%$ aq $\mathrm{KOH} /$ ethanol mixture provided quinones $\mathbf{4 a}, \mathbf{b}$ as a mixture. The two isomers were then separated and purified by column chromatography to give compounds $\mathbf{4 a}$ and $\mathbf{4 b}$ in $18 \%$ and $30 \%$ yields, respectively. It can be noticed that the condensation reaction has been performed several times, and in each case, for unknown reasons, anti/syn ADI isomers were always formed in a 1:2 ratio (anti/syn).

The isomers $\mathbf{4 a}$ and $\mathbf{4 b}$ present similar ${ }^{1} \mathrm{H}$ NMR spectra which provide no sufficient information for their identification (Figure S13, Supporting Information). On the contrary, ${ }^{13} \mathrm{C}$ NMR spectra (Figure S14, Supporting Information) of those two derivatives are slightly different in the $\mathrm{C}=\mathrm{O}$ chemical shifts region since in the first spectrum only one signal was observed and in the second one two signals were present. From a structural point of view, the anti-isomer possesses a $C_{2}$ symmetry, and the synisomer belongs to the $C_{2 v}$ symmetrical group. Therefore, only one NMR signal is expected for the $\mathrm{C}=\mathrm{O}$ carbon atoms in the anti-isomer ${ }^{13} \mathrm{C}$ NMR spectrum whereas two signals should be observed for the same carbon atoms in the $s y n$-isomer one. Thus, the anti-isomer $\mathbf{4 a}$ is assigned to the compound with one signal at $\delta_{(\mathrm{C}=\mathrm{O})}=183.7 \mathrm{ppm}$ and the $s y n$-isomer $\mathbf{4 b}$ is identified as the derivative which shows two $\mathrm{C}=\mathrm{O}$ signals at $\delta_{(\mathrm{C}=\mathrm{O})}=184.3 \mathrm{ppm}$ and $183.0 \mathrm{ppm}$ in its ${ }^{13} \mathrm{C}$ NMR spectrum.

The structural identification of both isomers were also independently confirmed by their structure determination by single-crystal X-ray diffraction. Single crystals were obtained by solvent evaporation from a THF solution for $\mathbf{4 a}$ and by slow diffusion of methanol into chloroform solution of the compound for $\mathbf{4 b}$ (see the Supporting Information).

Finally, ADI 5a (deep red solid) or $\mathbf{5 b}$ (deep red waxy solid) were achieved in $83 \%$ and $76 \%$ yield, respectively, by reaction of quinones $4 \mathbf{a}$ or $\mathbf{4 b}$ with the corresponding lithium intermediates of thiophene, followed by reduction/ deoxygenation using $\mathrm{SnCl}_{2}$ in $6 \mathrm{M} \mathrm{HCl}_{\mathrm{aq}}$ solution.

All compounds possess good solubilitities (up to $10^{-1} \mathrm{M}$ ) in several common organic solvents such as chloroform, dichloromethane, toluene, and tetrahydrofuran and were fully characterized by NMR and optical spectroscopies, mass spectrometry, and cyclic voltammetry (for $\mathbf{5 a}, \mathbf{b}$ ). Optical measurements were performed from chloroform

(10) Comins, D. L.; Killpack, M. O. J. Org. Chem. 1987, 52, 104.

(11) Cardona, C. M.; Li, W.; Kaifer, A. E.; Stockdale, D.; Bazan, G. C. Adv. Mater. 2011, 23, 2367.

(12) (a) Becke, A. D. J. Chem. Phvs. 1993, 98, 5648. (b) Lee, C.; Yang, W.; Parr, R. G. Phvs. Rev. B 1988, 37, 785. 
Scheme 1. Synthesis of Isomerically Pure anti- and syn-ADI Derivatives 5a,b

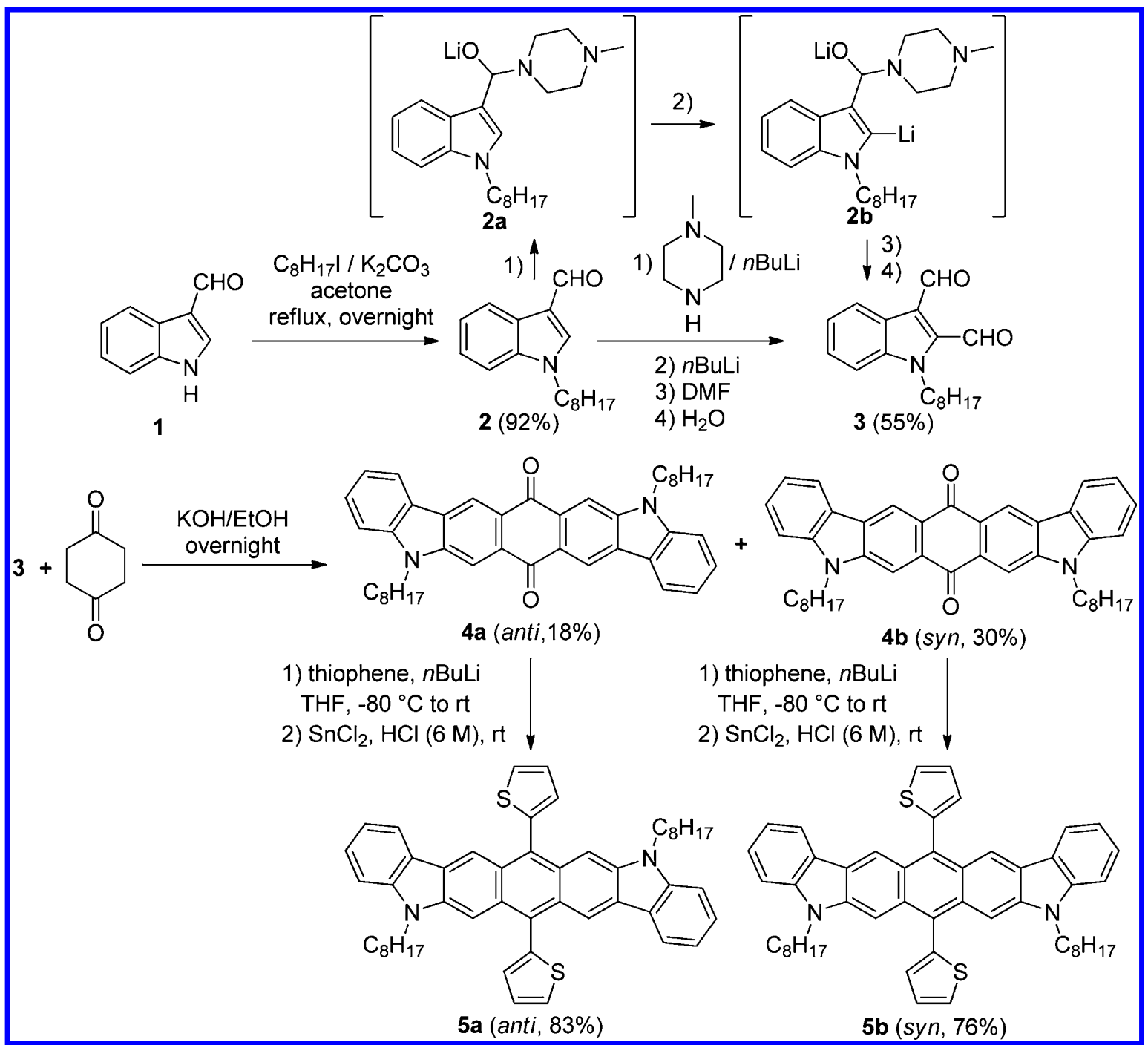

Table 1. Experimental Optical Data, Oxidation Potential Values $E_{1 / 2}=\left(E_{\mathrm{pc}}+E_{\mathrm{pa}}\right) / 2$ in V (vs Fc ${ }^{+} / \mathrm{Fc}$ couple) of ADI Derivatives 5a,b in $\mathrm{CH}_{2} \mathrm{Cl}_{2}$ Solution Containing $0.1 \mathrm{M}$ of TBAPF 6 at a Scan Rate of $100 \mathrm{mV} \cdot \mathrm{s}^{-1}$ and Their Estimated HOMO Energy Levels (eV), Calculated Vertical Transition Energies ( $\left.\Delta E_{\text {vertical }}\right)$ to the Lowest Excited State as Well as Calculated HOMO and LUMO Values of 5a,b in the Gas Phase

\begin{tabular}{|c|c|c|c|c|c|c|c|c|c|c|c|}
\hline \multicolumn{9}{|c|}{ experimental } & \multicolumn{3}{|c|}{ theoretical } \\
\hline compd & $\begin{array}{c}\lambda_{\mathrm{abs}} \\
{[\mathrm{nm}(\mathrm{eV})]}\end{array}$ & $\begin{array}{c}\lambda_{\mathrm{em}}{ }^{a} \\
{[\mathrm{~nm}(\mathrm{eV})]}\end{array}$ & $\begin{array}{l}E_{\mathrm{g}}{ }^{b} \\
(\mathrm{eV})\end{array}$ & $\begin{array}{c}E_{\text {ox1 }} \\
\text { (V) }\end{array}$ & $\begin{aligned} \Delta E= & E_{\mathrm{pc}}-E_{\mathrm{pa}} \\
& (\mathrm{mV})\end{aligned}$ & $\begin{array}{l}E_{\mathrm{ox} 2} \\
(\mathrm{~V})\end{array}$ & $\begin{array}{c}E_{\mathrm{ox} 3} \\
(\mathrm{~V})\end{array}$ & $\begin{array}{c}\mathrm{HOMO}^{c} \\
(\mathrm{eV})\end{array}$ & $\begin{array}{c}\Delta E \text { vertical } \\
{[\mathrm{nm}(\mathrm{eV})]}\end{array}$ & $\begin{array}{c}\text { HOMO } \\
(\mathrm{eV})\end{array}$ & $\begin{array}{c}\text { LUMO } \\
(\mathrm{eV})\end{array}$ \\
\hline anti-ADI $\mathbf{5 a}$ & $563(2.20)$ & $575(2.16)$ & 2.18 & 0.03 & 35 & 0.62 & & -5.13 & $552(2.25)$ & -4.45 & -1.85 \\
\hline syn-ADI $\mathbf{5 b}$ & $556(2.23)$ & $568(2.18)$ & 2.21 & 0.05 & 47 & $0.70^{d}$ & $0.87^{d}$ & -5.15 & $541(2.29)$ & -4.47 & -1.82 \\
\hline
\end{tabular}

solutions of the compounds and were compared to theoretical simulations. To do so, geometry optimizations was performed at the density functional theory (DFT) level, using the B3LYP functional ${ }^{12}$ and the $6-31 \mathrm{G}(\mathrm{d}, \mathrm{p})$ basis set. The octyl chains attached on the nitrogen atoms of the
ADI skeleton were replaced by methyl groups in the geometry optimizations to reduce the computational costs since they do not contribute to the description of the frontier electronic levels and hence the first absorption peaks. The pendant thiophene units are found to be perpendicular to 
the conjugated core in the optimized geometry, i.e., $92^{\circ}$ and $91^{\circ}$ for anti-ADI $\mathbf{5 a}$ and syn-ADI $\mathbf{5 b}$, respectively. The vertical transition energies to the lowest excited states of the isolated compounds were computed from the optimized geometries with the time-dependent density functional theory (TD-DFT) formalism ${ }^{13}$ using the same functional and basis set. The Gaussian 09 package was used for all calculations. ${ }^{14}$ anti-ADI 5a exhibits an absorption spectral profile similar to those of ADC showing an intense band below $400 \mathrm{~nm}$ and additional peaks located at lower energies (Figure S2, Supporting Information). ${ }^{2 \mathrm{a}}$ In the case of synADI 5b, two intense bands are observed below $400 \mathrm{~nm}$ in agreement with the calculated transition energies (Figure S2c, Supporting Information), and as for its isomer counterpart, several waves are present in the 400-600 $\mathrm{nm}$ range. For both isomers, beyond $500 \mathrm{~nm}$, the calculations yield a single optically coupled excited state involving a HOMO to LUMO electronic transition; therefore, the additional waves observed are assigned to vibronic satellites (Figure S2, Supporting Information). Small bathochromic shifts of $7 \mathrm{~nm}$ of the absorption and emission maxima are observed going from syn-ADI $\mathbf{5 b}$ to anti-ADI $\mathbf{5 a}$. The calculated transition energies follow the same behavior going from $\mathbf{5 b}$ to $5 \mathbf{a}(11 \mathrm{~nm}(0.04 \mathrm{eV}))$. The optical band gaps, listed in Table 1, were estimated from the intersection of the normalized absorption and emission spectra of ADI derivatives and are around $2.20 \mathrm{eV}$ for both isomers.

It was previously demonstrated that the reaction involved in the photoinduced degradation of fused linear (hetero)acenes can be compared to a Diels-Alder cycloaddition between the most reactive central ring of the (hetero)acenes and the $\mathrm{O}_{2}$ singlet formed upon UV-vis irradiation, which leads to the formation of an endoperoxide bridge. ${ }^{9 \mathrm{c}}$ Thereby, the stability of ADI derivatives toward photo-oxidation was investigated by monitoring the absorbance decay of $10^{-5} \mathrm{M}$ chloroform solutions and spin-coated thin films of ADI 5a,b stored in the dark at room temperature, under ambient atmosphere and exposed to $10 \mathrm{~cm}$ of an $8 \mathrm{~W}$ $\mathrm{UV}$-vis lamp $\left(\lambda_{1}=254 \mathrm{~nm}, \lambda_{2}=366 \mathrm{~nm}\right)$. In solution, both isomers present similar low stability toward photooxidation since their absorption decay is about $50 \%$ after $25 \mathrm{~s}$ of UV-vis lamp exposure (Figure S3, Supporting Information). It can also be noticed that upon irradiation of the $s y n$-isomer $\mathbf{5 b}$ a new broad band located around $690 \mathrm{~nm}$ appears. This latter band might be due to the formation of a radical-cation consecutive to an oxidation of the molecule. ${ }^{15}$ Several isosbectic points were noted in the $\mathrm{UV}$-vis spectrum of $\mathbf{5 a}$, thus indicating the coexistence in solution of two species: the starting derivative and its corresponding photo-oxidized species. Such phenomenon

(13) (a) Stratmann, R. E.; Scuseria, G. E.; Frisch, M. J. J. Chem. Phvs. 1998, 109, 8218. (b) Bauernschmitt, R.; Ahlrichs, R. Chem. Phvs. Lett. 1996, 256, 454. (c) Casida, M. E.; Jamorski, C.; Casida, K. C.; Salahub, D. R. J. Chem. Phvs. 1998, 108, 4439.

(14) See the Supporting Information for the full reference:Frisch, M. J. et al. Gaussian 09, revision A.02; Gaussian, Inc.: Wallingford, CT, 2009.

(15) (a) Balandier, J. Y.; Sebaihi, N.; Boudard, P.; Lemaur, V.; Quist, F.; Niebel, C.; Stas, S.; Tylleman, B.; Lazzaroni, R.; Cornil, J.; Geerts, Y. H. Eur. J. Org. Chem. 2011, 17, 3131. (b) Zade, S. S.; Zamoshchick, N.; Bendikov, M. Acc. Chem. Res. 2011, 44, 14. is, however, not observed for $\mathbf{5 b}$. This might imply that the degradation of the latter occurs following a more complex mechanism. In opposition, in thin films the stability of both ADI isomers are very different since anti-ADI $\mathbf{5 a}$ is much more stable than syn-ADI $\mathbf{5 b}$ by about a factor 3.6. For $50 \%$ of absorbance decay of the lowest energy bands of $\mathbf{5 a}$ and $\mathbf{5 b}$, their stability is about 5400 and $1500 \mathrm{~s}$, respectively (Figure S4, Supporting Information). A comparison of the X-ray powder diffraction patterns of both isomers is illustrated in Figure S32 (Supporting Information). For anti-ADI 5a, several diffraction peaks characteristic of a crystalline solid are observed while for syn-ADI $\mathbf{5 b}$ only an amorphous halo is noticed. Therefore, a better packing of the anti-ADI isomer $\mathbf{5 a}$ in the solid state is likely responsible of its higher photoresistance, the most reactive position becoming less accessible.

The electrochemical properties of ADI derivatives $\mathbf{5 a , b}$ were studied using cyclic voltammetry (Figure S33, Supporting Information) and are collected in Table 1. All measurements were also performed in a glovebox under argon atmosphere $\left(\mathrm{O}_{2}<1 \mathrm{ppm}\right)$ in order to avoid the presence in solution of the photo-oxidized corresponding species of 5a,b. anti-ADI 5a present two reversible waves at $E_{\mathrm{ox} 1}=0.03 \mathrm{~V}$ and $E_{\mathrm{ox} 2}=0.62 \mathrm{~V}\left(\mathrm{vs} \mathrm{Fc}^{+} / \mathrm{Fc}\right.$ couple $)$ which are ascribed to the oxidation of $\mathbf{5 a}$ into the corresponding radical-cation and dication species, respectively. syn-ADI $\mathbf{5 b}$ exhibits also multiple oxidative processes $\left(E_{\mathrm{ox} 1}=0.05 \mathrm{~V}\right.$, $E_{\mathrm{ox} 2}=0.70 \mathrm{~V}$ and $E_{\mathrm{ox} 3}=0.87 \mathrm{~V}$, vs $\mathrm{Fc}^{+} / \mathrm{Fc}$ couple) with the first reversible one at comparable potential with respect to its isomer counterpart. This corroborates the similar stability observed in solution for both isomers $\mathbf{5 a}, \mathbf{b}$ toward the photo-oxidation since $E_{\mathrm{ox} 15 \mathrm{a}} \approx E_{\mathrm{ox} 15 \mathrm{~b}}$.

In conclusion, pure syn- and anti-anthradiindole (ADI) were synthesized with global yields of $11.5 \%$ and $7.6 \%$, respectively. The isomeric configurations of ADI derivatives were proven by ${ }^{13} \mathrm{C}$ NMR as well as by X-ray diffraction experiments on single crystals of the quinone precursors $\mathbf{4 a}$, b. Both isomers present similar stability in solution toward photooxidation, while in thin films the anti-ADI isomer is more resistant due to a better organization in the solid state. The synthetic work described herein offers the opportunity for further studies on the performance of anti- and syn-ADI derivatives in organic field-effect transistors.

Acknowledgment. We thank the Région Wallonne for financial support, Pascal Gerbaux (UMons) for MS measurements, and the UK National Crystallography Service at the University of Southampton for XRD data collection on compound 4a. The work in Mons is also supported by the European Commission/Région Wallonne (FEDER Smartfilm RF project) and the OPTI2MAT excellence program (Région Wallonne). J.C. is a FNRS research director.

Supporting Information Available. Experimental procedures, optical studies, NMR, mass, theoretical spectra of new compounds, and crystal structure analyses of ADIQ 4a,b. This material is available free of charge via the Internet at http://pubs.acs.org.

The authors declare no competing financial interest. 